\title{
Performance of Physical Education Professionals from the Academia da Cidade Program in Primary Health Care in Recife
}

\author{
Atuação dos profissionais de Educação Física do Programa Academia da \\ Cidade na Atenção Básica à Saúde do Recife
}

Vandepaula Moraes Campos de Melo1,2, Emmanuelly Correia de Lemos², Alany de Mesquita Marins'1, Bruno César Rodrigues da Silva', Amanda Emmanuelly de Melo Tavares Albuquerque', Luís José Lagos Aros², Rafael Miranda Tassitano

\begin{abstract}
This cross-sectional, descriptive, quantitative study aimed to analyze the performance of physical education professionals from the Academia da Cidade Program (ACP) in Primary Health Care (PHC) in Recife, Brazil. The study included 104 professionals who worked in ACP centers in the city of Recife. Data were collected using a self-administered questionnaire. We also assessed variables related to participants' sociodemographic and professional profile, their performance in the ACP, out-of-center activities, and cooperation with PHC. Data were stored and organized using the EpiData software version 3.1 and then analyzed using SPSS version 10.0. Most professionals were female (61.5\%), aged 30 to 39 years old (76.9\%) and had not served any public health internships during their initial training (71.2\%). As for their performance in PHC, most professionals carried out out-of-center activities in the community $(77.3 \%)$, but these activities were not implemented in conjunction with the Family Health Units (68.3\%) nor with the Family Health Support Centers (75.7\%). Of those who implemented joint activities, $81.8 \%$ of participants built dialogue with community health agents. Furthermore, $57.7 \%$ stated that users' referral to Family Health Units occurred in an informal manner. We conclude that the performance of physical education professionals of the ACP in PHC in Recife has been made effective through the implementation of outof-center activities; however, these activities are not integrated with existing PHC strategies.
\end{abstract}

\section{Keywords}

Physical Activity; Professional Practice; Primary Health Care.

\section{Resumo}

O objetivo do presente estudo foi analisar a atuação dos profissionais de Educação Física do Programa Academia da Cidade (PAC) na Atenção Básica à Saúde (ABS) do Recife. Trata-se de estudo transversal, descritivo e de abordagem quantitativa, que foi realizado com 104 profissionais que atuavam nos polos do PAC no Recife. Para a coleta de dados, utilizou-se um questionário autoaplicado e foram mensuradas variáveis relacionadas ao perfil sociodemográfico e profissional, à atuação no PAC, às atividades extrapolo e à articulação com a ABS. A tabulação dos dados foi efetuada no programa EpiData v. 3.1 e para análise dos dados foi utilizado o software SPSS v. 10.0. A maioria dos profissionais era do sexo feminino (61,5\%), na faixa etária de 30 a 39 anos (76,9\%) e não vivenciou estágio em saúde pública durante a formação inicial (71,2\%). Quanto à atuação na ABS, a maioria dos profissionais desenvolvia ação extrapolo na comunidade (77,3\%), mas não desenvolvia ação conjunta com as unidades de saúde da familia (68,3\%) e nem com os núcleos de apoio à saúde da familia (75,7\%). Dentre os que realizavam, $81,8 \%$ afirmaram estabelecer diálogo com o agente comunitário de saúde. Em relação ao encaminhamento dos usuários para as unidades de saúde da familia, $57,7 \%$ informaram que realizava de maneira informal. Conclui-se que a atuação dos profissionais de Educação Física do PAC na ABS do Recife foi efetivada pelo desenvolvimento das atividades extrapolo, porém, realizada ainda de forma desarticulada das principais estratégias da $A B S$.

Palavras-chave

Atividade física; Prática profissional; Atenção primária à saúde.

\section{Introduction}

The Academia da Cidade Program (ACP) was first introduced in Recife in 2002 and is regulated by Municipal Decree Number 19.808 (of April $3^{\text {rd }}, 2003$ ), Municipal Decree Number 22.345 (October $18^{\text {th }}, 2006$ ), 
and Ordinance Number 122 (of September $\left.28^{\text {th }}, 2006\right)^{1}$. The ACP is a health promotion strategy designed to promote leisure-time physical activity and the adoption of healthy lifestyle behaviors among the citizens of Recife ${ }^{1}$. The program was developed in redesigned public spaces called "centers" and all activities are supervised by physical education professionals $(\mathrm{PEP})^{1}$.

The ACP was commended by the publication of the National Policy on Health Promotion (NPHP) in $2006^{2}$, as it complies with its principles and guidelines. Conversely, in order to meet the NPHP guidelines, health promotion interventions in daily primary health care (PHS) services must be incorporated through intrasectorial and intersectorial actions ${ }^{3}$.

In order to do so, in 2009 the ACP expanded its actions beyond its centers, with the goal of propagating the program's interventions by systematically implementing integrated activities in PHC. These activities are called out-of-center activities ${ }^{1}$ PEP implement the interventions at the center (3 hours/day) and at out-of-center sites (3 hours/day). The latter are referred to as "community" and are implemented within the area of the center, together with the Family Health Units (FHU) and other PHC services, and at the Centers for Psychosocial Support (CPSS) ${ }^{1}$.

The integration between the ACP and other services within the health care network $(\mathrm{HCN})$ requires redefining the work processes of the professionals who work in them. This is done with the aim of prioritizing the autonomy of and interaction between professionals, the community, and the family, and to ensure cooperation between different PHC services ${ }^{4-6}$.

Some studies indicate that PEP who work in PHC value multidisciplinary networking and consider it important; however, they identify difficulties and weaknesses in the system, from initial training to the work process ${ }^{7,8}$. In this sense, it becomes necessary that these professionals receive appropriate initial training and ongoing re-training, based on curricula that address the demands of public health ${ }^{9}$. This would make possible the establishment of appropriate relationships between all $\mathrm{HCN}$ actors, and overcome the problem of fragmented performance that still exists in public health practice ${ }^{6}$.

The ACP has been receiving recognition and been assessed with regard to the perception of users and non-users ${ }^{10}$, adherence ${ }^{11}$, professionals' conceptions ${ }^{12}$ and program effectiveness ${ }^{13}$. However, since the program has expanded its actions beyond its centers through the implementation of out-of-center activities, further studies need to investigate the performance of ACP professionals in $\mathrm{PHC}$, and their cooperation with other services of the health care network. Thus, the aim of this study was to investigate the performance of PEP from the ACP in PHC in Recife.

\section{Methods}

This cross-sectional, descriptive, quantitative study analyzed data from a larger project named "Insertion of the Academia da Cidade Program in Primary Health Care in Recife: perception of professionals from primary health care and the Academia da Cidade Program", conducted in 2015 to investigate the insertion of the ACP in PHC.

The study was conducted in 39 of the 41 currently existing ACP sites in Recife, which are distributed through all eight districts. The sites Centro Médico Ermírio de Moraes and Polo Experimental da Universidade de Pernambuco were excluded from the study because the work process in these sites differs from that of other ACP sites, both with regard to the enrollment of users and the activities performed at the sites.

The study population was composed of all PEP who worked at the 39 sites, except those who were part of the research team of this study, those who were 
members of the management team of the ACP and those who were on a leave of absence, sick leave or vacation. Thus, 64 out of 182 professionals who work in the ACP met the exclusion criteria and did not participate in the study. This resulted in 118 eligible subjects for participation.

Data were collected from June to August 2015 through visits scheduled during districtwide meetings, training meetings and at the professionals' working sites. Subjects who could not be contacted after four attempts were considered as lost. The data collection team was composed of ten postgraduate students of Physical Activity and Public Health from the University of Pernambuco, who had been properly trained to collect data.

The data were collected using a self-administered questionnaire, which contained objective questions based on studies ${ }^{14}$ assessing programs and interventions for the promotion of physical activity in $\mathrm{PHC}$ and according to the reality of the ACP. The questionnaire contained ten sections: sociodemographic and professional data; performance in the ACP; out-of-center activities; physical structure; equipments, materials, cleaning and safety; districtwide meeting; training meeting; level of satisfaction; absenteeism; social control; and coordination with primary health care. All the variables analyzed in this study are described in Chart 1.

\begin{tabular}{|c|}
\hline Sociodemographic variables and professional profile \\
\hline $\begin{array}{l}\text { - Sex (male, female) } \\
\text { - Age (measured on an interval scale and categorized as: 20-29 years, 30-39 years, 40-49 years and 50-59 years) } \\
\text { - Educational level (undergraduate degree, specialization, residency, Master's degree) } \\
\text { - Type of undergraduate degree (teaching degree, licenciatura, bacharelado, licenciatura e bacharelado) } \\
\text { - Studied the subject of public health at undergraduate level (yes, no) } \\
\text { - Served an internship in public health during undergraduate training (yes, no) }\end{array}$ \\
\hline Section "Performance in the ACP" \\
\hline $\begin{array}{l}\text { - Training to work in the ACP (yes, no) } \\
\text { - Length of time working in the ACP (measured on an interval scale and categorized as: -4 years, 5-7 years, 8-10 } \\
\text { years, 11-13 years) }\end{array}$ \\
\hline Section "Out-of-center activities" \\
\hline $\begin{array}{l}\text { - Implementation of out-of-center activities (yes, no) } \\
\text { - How the referral to out-of-center activities occurred (management team decision, personal decision) } \\
\text { - Location of out-of-center activities (community, CPSS, shelter) }\end{array}$ \\
\hline Cooperation with PHC \\
\hline $\begin{array}{l}\text { - Level of knowledge about PHC policies (very low, low, intermediate, high, very high) } \\
\text { - Level of knowledge about health care services in their working area (very low, low, intermediate, high, very high) } \\
\text { - Activities implemented in conjunction with FHU professionals (yes, no) } \\
\text {-Frequency of activities implemented in conjunction with FHU professionals (rarely, sometimes, almost always, always) } \\
\text { - Activities implemented in conjunction with FHSC professionals (yes, no) } \\
\text { - Frequency of ctivities implemented in conjunction with FHSC professionals (rarely, sometimes, almost always, always) } \\
\text { - Activities implemented with other health care services in their working area (yes, no) } \\
\text { - Frequency with which ACP professionals were invited by FHU professionals to create an ITP (never, rarely, } \\
\text { sometimes, almost always, always) } \\
\text { - FHU professionals with whom you talk and work together to implement integrated activities (none: yes, no; } \\
\text { physician: yes, no; nurse: yes, no; dentist: yesn no; nurse technician: yes, no; CHW: yes, no; others: yes, no) } \\
\text { - Referral from the ACP to the FHU with a referral letter (yes, no) } \\
\text { - Referral from the ACP to the FHU without a referral letter (yes, no) } \\
\text { - Referral from the FHU to the ACP with a referral letter (yes, no) } \\
\text { - Referral from the FHU to the ACP without a referral letter (yes, no) } \\
\text { - Participation in meetings of FHUs in their working area (yes, no) } \\
\text { - importance of integrating PEP from the ACP in PHC in Recife (not important, not really important, important, } \\
\text { very important) } \\
\text { - How ACP performance in PHC in Recife is rated (very bad, bad, moderate, good, very good) }\end{array}$ \\
\hline
\end{tabular}

CHART 1 -Variables analyzed to investigate the performance of physical education professionals from the ACP in PHC in Recife, Brazil, 2015.

ACP - Academia da Cidade Program; PHC - Primary Health Care; FHU - Family Health Unit; FHSC Family Health Support Center; ITP - Individual Therapeutic Project. 
Data were stored and organized using the EpiData software, version 3.1. All data were analyzed using the statistical program SPSS (Statistical Package for Social Sciences, version 10.0). The results are presented in absolute and relative frequencies.

The research project to which this study is connected was approved by the Ethics Committee on Human Research of the University of Pernambuco - CAAE: 45622215.8.0000.5192. All participation was voluntary and informed consent was obtained.

\section{Results}

Of 118 eligible subjects for participation, 2 refused and 12 were considered as lost. The main reasons for the loss of participants included lack of time and absence at the time of data collection after four failed attempts at contacting the subject.

The final sample consisted of 104 PEP from the ACP. The majority were female (61.5\%), aged $30-39$ years (76.9\%), had an undergraduate teaching degree (96.1\%), had not studied the subject of public health at undergraduate level (85.6\%) nor pursued an internship in this field (72.5\%). Conversely, most participants (67.3\%) had a specialization degree in the field of Physical Education - Table 1.

Most participants reported not having been trained to work in the ACP (73.1\%) and had been participating in the program for 2 years or longer (77.7\%). Most participants reported carrying out out-of-center activities (84.6\%), and that they had been referred to out-of-center activities by the management team $(51.2 \%)$ and that the "community" (77.3\%) was the place where their interventions took place. More than half of participants (67.3\%) reported having intermediate knowledge about PHC policies and services (FHU, CPSS, community centers, neighborhood associations) in the area where they work - Table 1.

TABLE 1 - Description of sociodemographic variables and professional profile, performance in the $A C P$, out-of-center activities and level of knowledge of physical education professionals from the ACP about other health care services in their working area, Recife, Brazil, 2015.

\begin{tabular}{lcc}
\hline Variables & $n$ & $\%$ \\
\hline Sex & 64 & 61.5 \\
\hline Female & 40 & 38.5 \\
\hline Male & & \\
\hline Age group & 4 & 3.8 \\
\hline 20-29 years & 80 & 76.9 \\
\hline 30-39 years & 18 & 17.4 \\
\hline 40-49 years & 2 & 1.9 \\
\hline 50-59 years & & 25.9 \\
\hline Educational level & 27 & 67.3 \\
\hline Undergraduate & 70 & 1.0 \\
\hline Specialization & 1 & 5.8 \\
\hline Residency & 6 & \\
\hline Master's degree & & 96.1 \\
\hline Type of undergraduate degree & 99 & 1.9 \\
\hline Teaching degree & 2 & 1.0 \\
\hline Undergraduate degree & 1 & 1.0 \\
\hline Bachelor's degree & 1 & \\
\hline Undergraduate and bachelor's degree & & \\
\hline
\end{tabular}


... continues.

\begin{tabular}{|c|c|c|}
\hline Variables & $\mathrm{n}$ & $\%$ \\
\hline \multicolumn{3}{|c|}{ Subject of public health at undergraduate level } \\
\hline Yes & 15 & 14.4 \\
\hline No & 89 & 85.6 \\
\hline \multicolumn{3}{|c|}{ Internship in public health during undergraduate training } \\
\hline Yes & 28 & 27.5 \\
\hline No & 74 & 72.5 \\
\hline \multicolumn{3}{|l|}{ Training to work in the ACP } \\
\hline Yes & 28 & 26.9 \\
\hline No & 76 & 73.1 \\
\hline \multicolumn{3}{|l|}{ Length of time working in the ACP } \\
\hline 2 to 4 years & 41 & 39.8 \\
\hline 5 to 7 years & 39 & 37.9 \\
\hline 8 to 10 years & 17 & 16.5 \\
\hline 11 to 13 years & 6 & 5.8 \\
\hline \multicolumn{3}{|c|}{ Implementation of out-of-center activities } \\
\hline Yes & 88 & 84.6 \\
\hline No & 16 & 15.4 \\
\hline \multicolumn{3}{|c|}{ How the referral to out-of-center activities occurred } \\
\hline Management team decision & 44 & 51.2 \\
\hline Personal decision & 42 & 48.8 \\
\hline \multicolumn{3}{|l|}{ Location of out-of-center activities } \\
\hline Community & 68 & 77.3 \\
\hline CPSS & 19 & 21.6 \\
\hline Shelter & 1 & 1.1 \\
\hline \multicolumn{3}{|c|}{ Level of knowledge about PHC policies } \\
\hline Very low & 0 & 0.0 \\
\hline Low & 24 & 23.1 \\
\hline Intermediate & 70 & 67.3 \\
\hline High & 10 & 9.6 \\
\hline Very high & 0 & 0.0 \\
\hline \multicolumn{3}{|c|}{ Level of knowledge about other health care services in their working area } \\
\hline Very low & 1 & 1.0 \\
\hline Low & 25 & 24.0 \\
\hline Intermediate & 70 & 67.3 \\
\hline High & 8 & 7.7 \\
\hline Very high & 0 & 0.0 \\
\hline
\end{tabular}

ACP - Academia da Cidade Program; CPSS - Center for Psychosocial Support PHC - Primary Health Care.

With regard to activities implemented in conjunction with other PHC professionals, most ACP teachers reported never having worked with FHU (68.3\%) or FHSC professionals $(75,7 \%)$ nor with any community centers or neighborhood associations in their working area (87.1\%). Likewise, most participants said that they did not participate in meetings ofthe FHU in their working area (93.1\%) and that they had "never" been invited (86.0\%) by their local FHU team to participate in the creation of an Individual Therapeutic Project (ITP, Projeto Terapêutico Singular) for FHU users - Table 2. 
TABLE 2 - Description of activities implemented in conjunction between physical education professionals and other primary health care services in their working area, Recife, Brazil, 2015.

\begin{tabular}{|c|c|c|}
\hline Variables & $\mathrm{n}$ & $\%$ \\
\hline \multicolumn{3}{|c|}{ Activities implemented in conjunction with FHU professionals } \\
\hline Yes & 33 & 31.7 \\
\hline No & 71 & 68.3 \\
\hline \multicolumn{3}{|c|}{ Frequency of activities implemented in conjunction with FHU professionals } \\
\hline Rarely & 5 & 15.2 \\
\hline Sometimes & 15 & 45.4 \\
\hline Almost always & 12 & 36.4 \\
\hline Always & 1 & 3.0 \\
\hline \multicolumn{3}{|c|}{ Activities implemented in conjunction with FHSC professionals } \\
\hline Yes & 25 & 24.3 \\
\hline No & 78 & 75.7 \\
\hline \multicolumn{3}{|c|}{ Frequency of activities implemented in conjunction with FHSC professionals } \\
\hline Rarely & 9 & 36.0 \\
\hline Sometimes & 8 & 32.0 \\
\hline Almost always & 6 & 24.0 \\
\hline Always & 2 & 8.0 \\
\hline \multicolumn{3}{|c|}{ Health care services in their working area } \\
\hline Yes & 13 & 12.9 \\
\hline No & 88 & 87.1 \\
\hline \multicolumn{3}{|c|}{ Participation in FHU meetings } \\
\hline Yes & 7 & 6.9 \\
\hline No & 95 & 93.1 \\
\hline \multicolumn{3}{|c|}{ Frequency with which ACP professionals were invited by FHU professionals to create an ITP } \\
\hline Never & 86 & 86.0 \\
\hline Rarely & 9 & 9.0 \\
\hline Sometimes & 5 & 5.0 \\
\hline Almost always & 0 & 0.0 \\
\hline Always & 0 & 0.0 \\
\hline
\end{tabular}

ACP - Academia da Cidade Program; PHC - Primary Health Care; ITP - Individual Therapeutic Project.

Community health workers (CHW) were reported as the FHU workers with whom PEP from the ACP most talked and worked together to implement integrated activities (81.8\%) - Table 3.

TABLE 3 - Description of FHU professionals with whom the physical education professionals from the ACP talk and work together to implement integrated activities, Recife, Brazil, 2015.

\begin{tabular}{lcc}
\hline Variables & $n$ & $\%$ \\
\hline None Professional & & \\
\hline Yes & 32 & 3.0 \\
\hline No & & \\
\hline Physician & 15 & 45.5 \\
\hline Yes & 18 & 54.5 \\
\hline No & & \\
\hline Nurse & 15 & 45.5 \\
\hline Yes & 18 & 54.5 \\
\hline No & & \\
\hline Dentist & & \\
\hline
\end{tabular}

Continues... 
... continues.

\begin{tabular}{lcc}
\hline Variables & $n$ & $\%$ \\
\hline Yes & 9 & 27.3 \\
\hline No & 24 & 72.7 \\
\hline Nurse technician & & \\
\hline Yes & 10 & 30.3 \\
\hline No & 23 & 69.7 \\
\hline CHW & & \\
\hline Yes & 27 & 81.8 \\
\hline No & 6 & 18.2 \\
\hline Others & & \\
\hline Yes & 8 & 75.8 \\
\hline No & 25 & 24.2 \\
\hline
\end{tabular}

ACP-Academia da Cidade Program; FHU- Family Health Unit; CHW- Community Health Worker.

Most professionals (58.3\%) stated that users' referral to FHU occurred in an informal manner, without a referral letter, and that users were not referred from the FHU to the ACP, neither in a formal manner, with referral letter (94.2\%), nor in an informal manner $(67.6 \%)$ - Table 4.

TABLE 4 - Description of referral practices between physical education professionals from the ACP and FHU professionals, Recife, Brazil, 2015.

\begin{tabular}{lcc}
\hline Variables & $n$ & $\%$ \\
\hline Referred the user to another service with a referral letter & & \\
\hline Yes & 87 & 84.5 \\
\hline No & & \\
\hline Referred the user without a referral letter & 60 & 58.3 \\
\hline Yes & 43 & 41.7 \\
\hline No & & \\
\hline User was referred to the ACP center with a referral letter & 6 & 94.8 \\
\hline Yes & 97 & 32.4 \\
\hline No & & 67.6 \\
\hline User was referred to the ACP center without a referral letter & 33 & \\
\hline Yes & 69 & \\
\hline No
\end{tabular}

ACP-Academia da Cidade Program; FHU- Family Health Unit.

When asked about the importance of integrating PEP from the ACP in PHC, $69.2 \%$ of respondents answered that it was "very important", $27.9 \%$ considered it "important" and 1.9\% thought it was "not really important". Lastly, $42.3 \%$ of respondents rated ACP performance in PHC as "good"; $22.1 \%$ as "very good"; $29.8 \%$ as "moderate"; $3.8 \%$ as "bad"; and $19 \%$ as "very bad".

\section{Discussion}

We found that most PEP working in the ACP had not served any public health internships during their initial training, nor had received any specific training to work in the program. Most participants do not implement activities in conjunction with PHC teams (FHU and FHSC). But when they do implement joint activities, these are done through dialogue with CHW. ACP referral to FHU, when made at all, occurred in an informal manner. Nevertheless, ACP professionals rated their 
performance in PHC in Recife as "very important" and "good".

With regard to the profile of ACP professionals, our findings are in line with other studies that found a predominance of young and female workers ${ }^{15-17}$. With regard to their initial training, we found that ACP professionals had not studied the subject of public health at undergraduate level nor had served public health internships. These results are consistent withprior research ${ }^{15,18}$. This shows that undergraduate physical education courses still offer a reduced number of subjects and internships in public health.

Anjos \& Duarte $^{9}$ analyzed the curriculum of undergraduate physical education courses and found that the subjects offered in these courses had a curative and therapeutic focus and that no internships were offered in the field of PHC. This evidences a disparity between training and the actual demand of health care services, which will have as a consequence the decontextualized performance of professionals.

Santos $\&$ Benedetti ${ }^{19}$ found that o internships effectively contributed to professional growth and improved care delivery to the general population, which would not only favor the integration but also improve the performance of PEP in PHC.

Despite having had limited training to work in PHC, most PEP in this study reported having intermediate knowledge about $\mathrm{PHC}$ policies and health care services provided in their working area. this could be due to the continuing education strategies that are systematically implemented by the ACP management team. This finding could also be explained by the daily work routine of these PEP, who carry out out-of-center activities in the community where they work.

Wefound that most PEP from the ACP do not implement activities in conjunction with the FHU, nor with the FHSC or with other health care services in their working area. Moreover, only a few respondents participated in FHU meetings and had been invited to participate in the development of ITPs for FHU users.

The lack of integration between ACP and PHC professionals found in this study corroborates the findings of other studies that investigated the work process of PEP from similar programs who worked invathe FHSC ${ }^{15,7}$. These findings evidence a fragmented health care system that organizes itself through a set of isolated health care settings that do not communicate with one another ${ }^{20}$. This is not consistent with national policy guidelines ofPHC, the National Policy on Health Promotion (NPHP) and the ACP, which presuppose a joint and continuous work in the context of PHC, in order to successfully achieve its goals ${ }^{1,3,6}$.

A study conducted with coordinators of physical activity programs financed by the Ministry of Health found that among the main difficulties experienced by coordinators were the lack of partnerships and little intrasectorial and intersectorial cooperation, which were reported by $13.1 \%$ of participants ${ }^{21}$.

Teamwork provides an opportunity to exchange experiences and develop collective work practices ${ }^{7}$. Thus, there is a need to implement functional health systems that integrate different HCN actors, in order to ensure users' access to activities and services that will solve their health problems and optimize the available resources ${ }^{22}$.

One important result that has to do with the cooperation between ACP and FHU professionals and needs to be highlighted here is the fact that the former seem to recognize CHWs as the main disseminators of the activities implemented in the program, due to the activities and bonds that CHWs create with health care users. Thus, there is a successful partnership between them, as seen in other studies conducted in other Brazilian regions ${ }^{23,24}$. 
Another point that needs to be highlighted is that in Recife users' referral from the ACP to the FHU and vice-versa still represents a challenge. The lack of communication about users between professionals evidences the fragmentation of the $\mathrm{HCN}^{22}$. In a qualitative and quantitative study ${ }^{12}$, PEP from the ACP rated interdisciplinary work and users' referral as important to the program. According to the data obtained in this study, users' referral to FHU occurred mostly in an informal manner. Mendes ${ }^{20}$ explains that care lines propose a therapeutic path for users in the network; they do not only work by means of established protocols, but also through the recognition that service managers can act together to reorganize the work process and facilitate users' access to the units and services they need.

The perception that PEP from the ACP have about the importance of their insertion in PHC may reflect their daily professional practice, which proves the benefits of physical activity to the health of the assisted population, both through activities implemented at the center and through out-of-center activities. In addition, the program is recognized as a successful experience, which served as a basis for the implementation of the Academia da Saúde Program at national levelel. Other studies ${ }^{7,18,26}$ have found similar results with regard to the insertion of PEP in PHC. According to them, this insertion represented a paradigm shift, reinforced the need for changes in the training, professional development and contribution to health services.

Further research may elucidate the main difficulties and barriers to network participation, especially with regard to the participation of ACP professionals or "similar others" in PHC, so that the common goal of delivering care to users can be achieved in the best possible way.

As this study is a cross-sectional study, it does not provide data to assess the state of affairs of interventions implemented in PHC, but, on the other hand, due to the goals of this research, it addresses the need to do so. Since this is one of the first studies to deal with out-of-center activities of the ACP, its findings contribute to the field of study of networking processes and may help visualize the strengths and weaknesses of such performances in PHC, in addition to serving as a basis for further studies.

Barriers to the implementation of activities in an integrated manner with PHC are not exclusive to the ACP. Developing actions related to physical activity in the context of the Unified Health System requires collective efforts, an ongoing dialogue between users, professionals, managers and the scientific community. The ACP management team, which is mainly composed of PEP, has been making sgnificant efforts to provide continuous training opportunities for workers.

Weconclude that the performance of PEP of the ACP in PHC in Recife has been made effective through the implementation of out-of-center activities; however, these activities are not integrated with existing PHC strategies (FHU and FHSC). This was confirmed by a lack of joint activities and by the lack of communication between services during the referral process of users.

\section{Acknowledgements}

We thank the research team for their cooperation in all phases of this research and the ACP professionals for answering the questionnaire and contributing to the creation of knowledge in this subject area. 
All the authors participated in project design or data analysis and interpretation, in drafting this manuscript and critically reviewing its intellectual content, and approved the final version to be published.

\section{References}

1. Lemos EC, Gouveia GC, Luna CF. Academia da Cidade Program: Recife's experience. In: Gurgel IGD, Medeiros KR, Aragão AA, Santana RM. Gestão em Saúde Pública: Contribuições para a política - Recife: Editora UFPE; 2014. p. 139-53.

2. Brasil. Ministério da Saúde. Secretaria de Vigilância em Saúde. Secretaria de Atenção à Saúde. National Health Promotion Policy/ Ministério da Saúde, Secretaria de Vigilânciaem Saúde, Secretaria de Atenção à Saúde. - Brasília: Ministério da Saúde, 2006.

3. Brasil. Ministério da Saúde. Secretaria de Vigilância em Saúde. Secretaria de Atenção à Saúde. National Health Promotion Policy: NHPP: review of Ordinance MS / GM No. 687 of March 30, 2006/ Ministério da Saúde, Secretaria de Vigilância em Saúde, Secretaria de Atenção à Saúde. Brasília: Ministério da Saúde. 2015.

4. Merhy EE. Work in health: seeing and experiencing the Unified Health System SUS daily. São Paulo: Hucitec, 2003.

5. Faria HX, Araújo MD. An analysis perspective on the work process in the area of

6. health: the production of care and the production of subjects. Saúde Soc. 2010; 19(2): 429-39.

7. Brasil. Ministério da Saúde. Secretaria de Atenção à Saúde. Departamento de Atenção Básica. National Primary Care Policy/ Ministério da Saúde. Secretaria de Atenção à Saúde. Departamento de Atenção Básica. Brasília: Ministério da Saúde. 2012.

8. Souza SC, Loch MR. Professional intervention in Physical Education at the Health Family Support Nucleus in municipalities in the North of Paraná. Rev Bras Ativ Fís Saúde. 2011; 16(1): 5-10.

9. Coutinho SS. Competencies of the Physical Education Professional in Primary Health Care [thesis] Ribeirão Preto: Universidade de São Paulo; 2011.

10. Anjos TC, Duarte AC. Physical Education and Family Health Strategies: training and professional performance. Physis (Rio J.) 2009; 19(4): 1127-44.

11. Hallal PC, Tenório MC, Tassitano RM, Reis RS, Carvalho YM, Cruz DK, et al. Evaluation of the Academia da Cidade program to promote physical activity in Recife, Pernambuco State, Brazil: perceptions of users and non-users. Cad Saúde Pública. 2010; 26(1): 70-8

12. Lemos EC. Determinants of adherence and non-adherence to the Programa Academia da Cidade, Recife-PE [thesis]. Recife: Centro de Pesquisas Aggeu Magalhães; 2012.

13. Hallal PC, Carvalho YM, Tassitano RM, Tenório MC, Warschauer M, Reis RS, et al. Quali-Quantitative evaluation of the "Academia da Cidade" Program from Recife, Brazil: Perceptions of the professionals working in the program. Rev Bras Ativ Fís Saúde.2009; 14(1): 9-14.

14. Simões EJ, Hallal PC, Pratt M, Ramos L, Munk MR, Damascena W, et al. Effects of a Community-Based, Professionally Supervised Intervention on Physical Activity Levels Among Residents of Recife, Brazil. Am J Public Health Res. 2009; 99(1): 68-75.

15. Silva JR. Actions for the monitoring and evaluation of interventions for the promotion of physical activity in Primary Health Care in the State of Pernambuco. [dissertation] Recife: Universidade de Pernambuco; 2015.

16. Guarda FR, Silva RN, Feitosa WM, Neto PM, Araújo Júnior JL. Characterization of physical activity program teams and their work process. Rev Bras Ativ Fís Saúde. 2016; 20(6): 638-49.

17. Wermelinger M, Machado MH, Tavares MF, Oliveira ES, Moysés MN. Workforce at the Health Sector in Brazil: Focusing on Feminization. Divulg Saúde Debate. 2010; 45: 54-70.

18. Tomasi E, Facchini LA, Piccini RX, ThuméE, Silveira DS, Siqueira FV, et al. Epidemiological and socio-demographic profile of primary care workers in the South and Northeast of Brazil. Cad Saúde Pública. 2008; 24(Suppl 1): 193-201.

19. Falci DM, Belisário SA. Position of physical education professionals within primary healthcare and the challenges in their training. Interface Comum Saúde Educ. 2013; 17(47): 885-99.

20. Santos SF, Benedetti TR. The implementation of the Family Health Support Center and the 
insertion of physical education professionals. Rev Bras Ativ Fís Saude. 2012; 17(3): 188-94

21. Mendes EV. Health care networks. Ciênc Saúde Coletiva. 2010; 15(5): 2297-305.

22. Amorim TC, Knuth AG, Cruz DK, Malta DC, Reis RS, Hallal PC. Description of the physical activity promotion programs funded by the Brazilian Ministry of Health. Rev Bras Ativ Fís Saúde. 2013; 18(1): 63-74.

23. Sousa FO, Medeiros KR, Gurgel Júnior GD, Albuquerque PC. From normative aspects to the reality of the Unified Health System: revealing barriers that curtail access to the health care network. Ciênc Saúde Coletiva, 2014; 19(4): 1283-93.

24. Gomes MA, Duarte MF. Effectiveness of physical activity interventions to promote health in adults covered by the Family Health Strategy: Ação e Saúde Program, Florianopolis, Brazil. Rev Bras Ativ Fís Saúde. 2008; 13(1): 44-56.

25. Silva L, Matsudo S, Lopes G. From diagnosis to action: Community program of physical activity in primary care: the experience of the São Caetano do Sul city, Brazil. Rev Bras Ativ Fís Saúde. 2001; 16(1): 84-8.

26. Lemos EC, Paes IM, Abath MB, Brainer MG, Lima JI. Monitoring Program of the Academy of Cities and Health: the experience of Pernambuco. Rev Bras Ativ Fís Saúde. 2015; 20(2): 203-7.

27. Pedrosa OP, Leal AF. Insertion of the Physical Education Professional into the Family Health Strategy in a capital in the North of Brazil. Movimento. 2012; 18(2): 235-53.

\section{CORRESPONDING}

AUTHOR

VANDEPAULA MORAES CAMPOS DE MELO

vandepaulamoraes@yahoo.com.br
Rua Princesa Isabel, 83 , apt ${ }^{\circ} 1102$, Santo Amaro, CEP: 50050-450 Recife-PE, Brazil. Phone: (81)99655-3071 / (81)988071665 .
RECEIVED

$01 / 12 / 2015$ $03 / 02 / 2016$ $19 / 03 / 2016$ $04 / 05 / 2016$ $30 / 05 / 2016$

APPROVED 05/06/2016 